This is an electronic reprint of the original article. This reprint may differ from the original in pagination and typographic detail.

Author(s): Sihto, Tiina

Title: Local childcare policy and the changing gender contract

Year: $\quad 2018$

Version:

Please cite the original version:

Sihto, T. (2018). Local childcare policy and the changing gender contract.

International Journal of Sociology and Social Policy, 38(1/2), 87-102.

https://doi.org/10.1108/IJSSP-12-2016-0139

All material supplied via JYX is protected by copyright and other intellectual property rights, and duplication or sale of all or part of any of the repository collections is not permitted, except that material may be duplicated by you for your research use or educational purposes in electronic or print form. You must obtain permission for any other use. Electronic or print copies may not be offered, whether for sale or otherwise to anyone who is not an authorised user. 


\section{emeraldinsight}

\section{International Journal of Sociology and Social Policy}

Local childcare policy and the changing gender contract

Tiina Sihto,

\section{Article information:}

To cite this document:

Tiina Sihto, "Local childcare policy and the changing gender contract", International Journal of Sociology and Social Policy,

https://doi.org/10.1108/IJSSP-12-2016-0139

Permanent link to this document:

https://doi.org/10.1108/IJSSP-12-2016-0139

Downloaded on: 18 December 2017, At: 22:52 (PT)

References: this document contains references to 0 other documents.

To copy this document: permissions@emeraldinsight.com

Access to this document was granted through an Emerald subscription provided by emerald-srm:306933 []

\section{For Authors}

If you would like to write for this, or any other Emerald publication, then please use our Emerald for Authors service information about how to choose which publication to write for and submission guidelines are available for all. Please visit www. emeraldinsight. com/authors for more information.

\section{About Emerald www.emeraldinsight.com}

Emerald is a global publisher linking research and practice to the benefit of society. The company manages a portfolio of more than 290 journals and over 2,350 books and book series volumes, as well as providing an extensive range of online products and additional customer resources and services.

Emerald is both COUNTER 4 and TRANSFER compliant. The organization is a partner of the Committee on Publication Ethics (COPE) and also works with Portico and the LOCKSS initiative for digital archive preservation.

*Related content and download information correct at time of download. 


\title{
Local childcare policy and the changing gender contract
}

\begin{abstract}
Purpose: The aim of this article is to examine the changes in local childcare policy that have taken place between the years 2008 and 2016 in the city of Jyväskylä, Finland, and to study how the local gender contract for women is being reshaped via these transformations in local policy.

Design/Methodology/Approach: Case study was applied as a research strategy. Local and national level statistics were used to explore the use of childcare services. Documents regarding the decision-making and administration of childcare in the city were analysed to distinguish the local policy changes during the time period. These documents include city budgets and records from the two municipal boards that have held the administrative responsibility of local childcare policy. The analysis of the data was conducted by using document analysis and feminist content analysis as a methodological framework.
\end{abstract}

Findings: The results show that the overall development in local childcare policy has been towards cutbacks in childcare services and benefits, and towards the marketisation of childcare services. The city has also implemented new, locally specific childcare policies, which constitute a hybrid form of marketisation and neofamilism. Together these developments are creating a new local gender contract, which goes beyond the past previous traditional or modern models. This new local gender contract for women is defined as that of 'entrepreneurial homemaker'.

Originality/Value: This paper contributes to the research on local social policy by identifying the role of local childcare policy in reshaping the gender contract in a Nordic context. This paper advances the theorisation of the concept of gender contract by introducing the 'entrepreneurial homemaker' model of gender contract.

Keywords: childcare, Finland, gender contract, local social policy, marketisation

Type: Research paper 


\section{Introduction}

This article analyses the changes in local childcare policy and the ways in which these changes are reshaping the local gender contract for women in Jyväskylä, a middle-sized Finnish city. In this article, the analysis of childcare policy focuses on the provision of services and benefits which are offered for families with children below the school age (aged $0-6)$. The changes in childcare policy are further analysed through the framework of 'local gender contract' (Forsberg, 1998). This study focuses on the time period of the economic downturn that started in 2008 and the following years which have been characterised by the implementation of various austerity measures in social policy. The main research questions of this article are: What changes have occurred in the local childcare policy in the city of Jyväskylä between 2008 and 2016? How is the local gender contract in the city being reshaped via these changes in local childcare policy?

In this article, local childcare policy is used as a lens through which the changes in the local gender contract are analysed. This is due to the importance that the development of childcare policy has had for the Finnish gender contract and the women-friendliness (Hernes, 1987) of the Nordic welfare model. Historically, the development of childcare policy and the availability and access to publicly funded childcare services has been central in formulating the gender contract between women and the state in Finland (Julkunen, 1994) and the availability of high-quality childcare services has been regarded as a key characteristic of the women-friendly policies in Nordic countries (Leira, 2002). Which childcare arrangements are supported, promoted and made appealing to mothers, and which are not, offers an idea to what is socially and culturally expected of mothers and women in general in relation to work and family. Therefore, changes in childcare policy offer a lens through which to observe the shifts in the gender contract and in the 'place' of women.

\section{Local gender contract}

The concept of gender contract refers to the ways in which gender relations are structured in families, labour markets and politics (Hirdman, 1996), and what the overall sociocultural consensus is on the roles and places of men and women (Perrons, 1995). Historically, changes in gender contract have usually been related to what the 'place' of women is in families and in the labour market. Also in this article, the explicit focus is on the reshaping of gender contract for women.

Finnish national gender contract has been built on the ideal of wage-worker motherhood (Rantalaiho, 1994), where periods of temporary homemaking exist, but where, for the greater part of their lives, women are in full-time employment (Salmi, 2006; Statistics Finland, 2012). In Finland, the majority of women are in full-time employment, including mothers of young children. In 2015, the employment rate of women was $67.7 \%$. (Statistics Finland, 2016a.) However, Koskinen Sandberg (2016) has argued that the recessions of 1990s and 2000s, globalisation, the uncertainty in the labour market and the rise of neofamilistic values, which draw from the past ideals regarding traditional family values (Jallinoja, 2006) and emphasise the importance of mothers in the upbringing and care of children (Salmi, 2006), have contributed to the emergence of a new national gender contract in Finland. This 
new gender contract, which she identifies as 'precarious worker/temporary homemaker contract' (p.25, 55), relies less on the idea of work as a source of citizenship for women, and more on the neofamilistic tendencies that emphasise women's traditional caring role in families.

Under the national gender contract, there exists a variety of other gender contracts. For example, different fields of work and different localities have their own gender contracts which are more or less tied to developments at the national level. In this article, the focus is on the 'local gender contract' in the city of Jyväskylä. This local gender contract can be seen as a particular place-specific variation of the Finnish national gender contract. Forsberg $(1998 ; 2001 ; 2010)$ defines local gender contract as the regional and spatial variations in the unwritten rules that regulate relations between genders. These rules are formed and renegotiated in the relations and actions that take place in a particular location, within its structures and everyday practices. Analysing gender contract specifically at the local level helps in identifying the spatial variations and place-specific negotiation gaps in the dynamic of gender relations (Forsberg, 2010).

Forsberg $(1998 ; 2001 ; 2010)$ has identified three ideal types of the regional variation in the gender contract in Sweden: traditional, modernised and non-traditional. The areas where the traditional gender contract is predominant have strong segregation in the labour market and high levels of family-based care, despite the Swedish national gender contract emphasising gender equality. Modernised gender contract is defined as having lower levels of employment segregation and more emphasis on public sector care. Non-traditional gender contract is defined as being in between traditional and modern gender contract, predominant in areas where the economic base is traditional, but where gender relations are more equal than in the traditional regions. Especially in rural areas, where traditional gender contract is often prevalent, women following modern gender contract might find out-migration to be an equality and career strategy (Grimsrud, 2011). However, decisions to move are rarely straightforward as the strategies that women adapt are often fundamentally shaped by their family situation (Ikonen, 2013; Jolkkonen, 1998).

Changes in the gender contracts often happen slowly and subtly (Caretta \& Börjeson, 2015). Thus, the developments in gender contracts over time and space are not necessarily easily distinguished, and the existing structures can also hinder these changes. In a study on the connection between region, work and gender in Finnish Lapland, Kari-Björkbacka (2015) argues that gendered local economy separates men and women through the value that is placed on investing in the male-dominated industries which are seen as profitable for the economy. At the same time, female-dominated work in the fields of social and health care is seen as an item of expenditure. According to Kari-Björkbacka (ibid.), local economy invites men and women to occupy traditional gender roles: men as the breadwinners and women as the supplementary wage-earners, ignoring the role of highly educated women in Lapland. Thus, local economy acts as a restorative element in Lapland's local gender contract instead of challenging the prevailing gender order. Women are encouraged to either invest in home and motherhood, or migrate to southern escalator regions in search of better employment opportunities and upward social mobility (Kari, 2009; Forsberg, 1998). When compared with the idea of local gender contract, Kari-Björkbacka (2015) sees the dynamic of gender relations as more static due to the strong role of local economy in putting men and women 
back to their traditional 'places'.

Following Forsberg $(1998 ; 2001 ; 2010)$, local gender contract is in this article understood as dynamic and changing over time. Even though this article focuses on changes in local gender contract in Jyväskylä, these developments are understood as intertwined with changes that are happening in national social policy and in the normative basis of the Finnish gender contract (Koskinen Sandberg, 2016). However, this intertwinement is not understood only as the national affecting the local, as the ways in which gender relations are lived, conserved, produced and reproduced in everyday life at the local level also play an important part in reshaping the national gender contract.

\section{Local childcare policies in the frame of national regulation}

In Finland, the relation between the local and the national - between municipalities and the state - in the organisation of social policy has been described as representing decentralised universalism (Burau \& Kröger, 2004). The system simultaneously, and somewhat paradoxically, emphasises national-level universalism by attempting to make welfare equal, not only by social status, but also by geographical location, whilst still maintaining the strong local autonomy of municipalities. This sometimes conflicting relation between the municipal and the national level creates the core of the 'Nordic welfare municipality' (Kröger, 2011).

An example of this conflicting relation between the municipal and the national level can be seen in the organisation and financing of care for young children (Haataja, 2012). In Finland, the state, together with employers and employees, finances maternity allowance until the child is about three months old, followed by parental allowance for mother or father until the child is nine to ten months old. Both maternity and parental leave periods are compensated according to previously taxed earnings. After the parental leave period ends, municipalities are responsible for organising child day care. However, if the family opts not to use formal child day care services, child home care allowance can be claimed by families with a child under the age of three who is not in municipal day care and who is looked after by one of the parents or another person, e.g. a relative. (Kela, 2014.) Both the division of the seemingly gender-neutral parental allowance and child home care allowance are extremely gendered. Mothers use $96 \%$ of parental leave days (Lammi-Taskula \& Salmi, 2013) and $93.1 \%$ of child home care allowance days (Findikaattori, 2016). Thus the choice of whether and when to enrol child in day care has strong gendered consequences, as in the majority of cases, the parent staying at home with children is the mother.

As the child home care allowance is paid at a low flat rate - 341.27 EUR per month in 2016 (Kela, 2016) - the direct costs of organising child day care are much higher for the municipalities than the costs of having the parent stay at home with the child on child home-care allowance until the child turns three years old. Thus, municipalities have the incentive to encourage maternal home-care of children, and many municipalities have opted to offer additional financial supplements for families using the child home-care allowance. In 2008, around half of the population in Finland lived in municipalities where this additional supplement was available. (Miettunen, 2008.) A contradiction between the municipal and the national level goals emerges as municipalities have the incentive to encourage maternal home-care for children, whereas at the national level, the aim is for gender equality and 
raising the employment level of the working-age population (Haataja, 2012; Autto, 2016).

\section{Data and Methods}

Selecting the case: city of Jyväskylä

The site of this study is Jyväskylä, a city located in Central Finland, approximately 300 kilometres north of Helsinki. As of 2016, Jyväskylä is the seventh largest city in Finland, with around 130,000 inhabitants. The economic structure of the city relies on services, as $79.2 \%$ of jobs are in the service sector, the Finnish national average being 73.8\% (Statistics Finland, 2016b). As a university city with a highly educated workforce, Jyväskylä could be seen as a city where modern gender contract is prevalent and as an 'escalator region' offering opportunities of social mobility for both men and women (Forsberg, 1998; 2010). However, in spite of the overall high educational level of the population, the city has also struggled with a high level of unemployment ever since the 1990s depression, as can be noted from table 1 . In 2015, the employment percentage in Jyväskylä was $17.6 \%$, when compared with the national average of $13.4 \%$. The unemployment percentage for women was lower both nationally $(11.8 \%)$ and locally $(15.6 \%)$ when compared with the unemployment percentage for men (SotkaNet, 2017.)

\section{TABLE 1 TO FEATURE HERE}

Jyväskylä was chosen as a site for this study, as it is a city that has been hailed a forerunner in both finding new and innovative solutions to organizing child day care (Saari et al., 2009) and in the implementation of service voucher (Suomen yrittäjät, 2015) in Finland. Therefore in the national context, Jyväskylä offers a rather unique case, which can be expected in the analysis to differ from the country average. However, due to the role of the city as a forerunner, the case of Jyväskylä also offers a view into one possible future towards which the other municipalities in Finland and the overall Finnish model of organizing child day care could be developing.

Data

In order to obtain in-depth information about local practices and to give a comprehensive look at the development of local childcare policy, a case study method was applied. Case study is an empirical inquiry that investigates a contemporary phenomenon in-depth and within its real-life context (Yin, 2009). This case study is based on two sources of information: local and national level statistics from SotkaNet indicator bank are used to explore the use of childcare services. Documents regarding the decision-making and administration of childcare policy in the city of Jyväskylä are analysed to distinguish the local policy changes during this time period. These documents cover the years 2008 to 2016. They include city budgets for 2009 to 2016 and records from the two municipal boards that have held the administrative responsibility of local childcare policy and early childhood education: 1) records from the Board of Social Services and Health (44 records from 18.12.2008 to 31.12.2011) and 2) the Board of Education (54 records from 1.1.2012 to 9.11.2016). For full list of documents 
analysed, see the appendix. ${ }^{1}$

\section{Document analysis and feminist content analysis as analysis methods}

The analysis of the data was conducted by using document analysis and feminist content analysis as a methodological framework. Document analysis involves skimming (superficial examination), reading (thorough examination) and interpretation of the data (Bowen, 2009). Content analysis is the process of organising information into categories related to the central questions of the research (Bowen, 2009, Leavy, 2007). At the first stage of the analysis, when the data was skimmed, read and re-read, the first aim was to achieve an understanding on what had been the policy alignments in the city between the years 2008 and 2016 . Consequently, categories regarding policy changes were formed. The categories that were formed were reforms (implementation of new forms of services or benefits for childcare), abolishments (abolishing existing services or benefits) cutbacks (cuts in the level of services or benefits) and increases (raising the level of services or benefits). This categorisation was done in order to answer to the first research question regarding what changes have occurred in the local childcare policy in the city of Jyväskylä between 2008 and 2016.

The second aim of this article was to analyse how the local gender contract in Jyväskylä is being reshaped via the changes that have taken place in local childcare policy. For this purpose, the categories that had been previously created were examined from the viewpoint of feminist content analysis (Leavy, 2007) in order to make visible the gendered consequences of local childcare policy changes. By feminist content analysis Leavy (ibid.) means critically interrogating texts and other cultural artefacts through a gender-sensitive lens. This seems particularly appropriate to analyse how childcare policy changes shape the local gender contract, as previous study by Autto (2016) has shown how local policy making regarding child day care in Finland is a context where gender is often largely absent, even though the implementation of particular childcare policy has gendered consequences. Thus the expectation before starting the analysis was that there would be very little, if any, discussion regarding gender in the local policy documents and that feminist methodology would be needed in order to read gender from the seemingly ungendered textual data. Feminist content analysis was chosen as a method, as it allows the researcher to examine gender in textual contexts where gender is not explicitly visible. For this article, feminist content analysis offered a way to examine the presence and absence of gender local policy documents, and to analyse what the changes in childcare policy mean for the local gender contract for women.

\section{Local and national trajectories of childcare}

\section{Use of municipally funded child day care services}

\footnotetext{
1 The state administrative responsibility of early childhood education was relocated from the Ministry of Social Affairs to the Ministry of Education and Culture in 2013. The then-upcoming change at the national level was reflected at the city level, as the administration of child day care services was moved in Jyväskylä from the Board of Social Services and Health to the Board of Education from the beginning of 2012.
} 
In Finland, all children below school-age have a social right to day care, regardless of the parent's employment or socioeconomic status. The cost of child day care is dependent on the income of parent(s) - the higher the income, the higher fee the parents pay for child day care services. Since 1973 municipalities have been responsible for organising child day care according to local need. Children in formal day care are taken care of either in a day care centre or in family day care. In family day care, the care provider looks after the children in the care providers' home, in a group that constitutes a maximum of four children (Alila et al., 2014).

The ideal of free choice for families in selecting their preferred form of childcare is strong in Finland (Varjonen, 2011). This 'freedom to choose' between different child day care service providers has been gradually expanding, together with the growing role of marketisation of services, since the 1990s. The first experiment on marketisation of child day care services was done in 1995 (Heikkilä \& Törmä, 1996). The Act on Child Home Care and Private Day Care Allowance (1128/1996) went into effect in 1996, opening doors for the marketisation and private provision of childcare services. Currently parents can choose between municipal or private child day care, although the availability of private child day care services and support for the use of private services varies between municipalities.

The Act on Service Vouchers for Social Welfare and Health Care (569/2009) went into effect in 2009, providing municipalities with the opportunity to use service vouchers for the delivery of social and health care services. Municipalities have the freedom to choose whether to implement the voucher or not, on which services and to what extent. Some municipalities, like Jyväskylä, have opted to offer the use of private services by offering service vouchers to parents for the purchasing of private child day care services. Consequently, the use of private child day care services varies between municipalities, depending particularly on the level of provision offered for the purchasing of private services.

When comparing the local and national developments in the use of municipally funded full-time day care, the local and national trajectories differ, as can be seen from table 2 . The share of children between ages one and six in municipally funded day care has been declining in Jyväskylä. In 1997, 57.3\% of children in this age group were in municipally funded full-time day care in Jyväskylä. In 2014, this figure stood at 48\%. The national trend during the same time period was the opposite - the share of children in municipally funded full-time day care rose from $53.9 \%$ in 1997 to $57.8 \%$ in 2014 . The progression for children of all age groups has been similar: in Jyväskylä, the use of municipally funded day care has decreased, whereas nationally it has increased (SotkaNet, 2016a). A likely explanation for the falling numbers of children in municipally funded full-time day care in the city is the growing use of service vouchers in purchasing private child day care services.

\section{TABLE 2 TO FEATURE HERE}

In Jyväskylä, families have also started to opt more for the use of part-time day care, whereas the national trend has been the opposite (SotkaNet, 2016a). This trend of part-time child day care in the city is likely to continue in the future as, starting from August 2016, changes in national legislation have made it possible for municipalities to limit the social right to child day care from full-time to part-time if the parent(s) of the child is staying at home (e.g. on 
parental leave or due to unemployment). Some municipalities chose not to limit the right to full-time day care. However, Jyväskylä was one of the municipalities that opted for the limitations (SIVLTK:24.2.2016).

\section{Cutbacks and marketisation of child day care services}

As noted in the previous section, the local level use of different child day care services can vary considerably from the country average. This section explores with more depth the case of Jyväskylä and the overall developments in childcare policy that have taken place since 2008 . During the recession and the following years, the economic situation in the city tightened. Simultaneously with economic difficulties, the need for formal childcare services increased, as the number of children below the school-age rose in the city (PTLTK:18.12.2008). Due to these developments, cutbacks were made on childcare services and benefits that offered something 'extra' in addition to the basic services that must be legally provided. This was also one of the responses that the Finnish municipalities had for the deep economic depression of the 1990s (Karisto et al., 1997).

Cutbacks that have been made in local childcare policy post-2008 have hit both familistic and defamilistic policies. Familistic policies refer to policies which are seen as encouraging maternal home care of children, e.g. cash-for-childcare, whereas defamilistic policies refer to policies which are seen as facilitating mother's labour market participation (Salmi, 2006), e.g. available and affordable child day care. An example of the cutbacks in familistic childcare policy is the abolishment of the additional supplement to child home care allowance. In 2000, the city of Jyväskylä began paying a 100 EUR supplement per child if all children in the family that were below the school age were in home care. In 2013, the level of the supplement was cut to 50 EUR (SIVLTK:19.3.2014), and, in 2014, the supplement was abolished (SIVLTK:18.3.2015). Following these developments, not only did the number of children in municipally financed day care decrease, but so did the number of families using child home care allowance for home care of their own children (SotkaNet, 2016b).

In addition to cutbacks, the city has been searching for more cost-effective solutions for organising services and managing the growing need for day care. In local policy documents, it is estimated that marketisation of child day care services will offer, at least, a partial solution to these problems. Following Brennan et al. (2012), marketisation is here defined as local government measures which "authorise, support or enforce the introduction of markets, the creation of relationships between buyers and sellers and the use of market mechanisms" to allocate childcare. According to estimations done by the city, places in private day care offer a less expensive solution to the city when compared with places in public day care (SIVLTK:16.4.2014). Consequently, the budgetary goals have gone towards a rapid increase in the use of private day care services. For 2010, the aim was that $7 \%$ of children between ages 0-6 would be under private day care services (The budget of city of Jyväskylä, 2010); for 2016, the goal was set at 14.1\% (The budget of city of Jyväskylä, 2016). The aim of marketisation of childcare services has been to 'encourage private service production and increase families' freedom of choice in selecting services,' (PTLTK:18.12.2008). As noted in previous research (e.g. Varjonen, 2011), the ideal of 'choice' fits the bigger picture of Finnish national childcare policy. Existing user surveys also 
show how the users of private childcare services in the city have been overall satisfied with the quality and price of the services (Saari et al., 2009).

These local developments towards marketisation are, inevitably, tied together with the national level changes that have occurred in the previous decades, such as the implementation of the Act on Child Home Care and Private Day Care Allowance (1128/1996) and the Act on Private Day Care Allowance and the Act on Service Vouchers for Social Welfare and Health Care (569/2009). These national level developments have, in turn, made the local level policy changes towards marketisation possible. Whether marketisation affects the access to services has only briefly been addressed in local policy documents, with the statement that after privatisation 'low-income families' access to services will possibly be weakened,' (PTLTK:23.4.2009). Overall, the meaning and consequences of marketisation of child day care has not yet been widely addressed in public discussion in Finland, even though this development is likely to have its own gender and class implications (Mahon et al., 2012). Previous studies (e.g. Penn 2009; Lloyd \& Penn 2010) in other country contexts have underlined the problems embedded in the marketization of childcare: it is highly debatable whether private provision will truly enhance the quality or cost-effectiveness of child day care. The next section of this analysis looks more closely into two intertwining local developments of marketisation and their possible implications for the local gender contract: the implementation of 'service money' and the growing popularity of private family day care.

\section{Reshaping the local gender contract - The role of service money and private family day care}

\section{Service money for childcare}

'Service money' for childcare was implemented in 2009 in the city. Originally, service money was intended as a replacement for all of the existing financial provisions for private child day care (PTLTK:18.12.2008). Due to service money being a local level innovation, and thus not under national legislation, the city had considerable leeway in defining on which conditions families would be eligible for the benefit.

This leeway was used when the Christian Democrats, a relatively small political party in the local government, proposed changes to the conditions on which service money was given in 2010. First proposition was that families with four or more children under school age in home care would receive service money. Second proposition was that service money would also be available for private family day care providers for the care of their own children who are below the school age, if the private family day care provider was caring for at least one 'care child' in addition to the family's own children. It was estimated that these changes proposed by the Christian Democrats would 'save 5.6-7 million euros from investments if 300 children will move from day care centres to family day care'. (PTLTK:22.4.2010.) This is one of the examples from the local policy documents where changes are first and foremost justified with financial considerations (see Kari-Björkbacka, 2015). Possible advantages or disadvantages of service money are discussed without referring to gender, and thus the possible gendered implications of these changes remain hidden in the local policy documents (see Autto, 2016): 
"The advantages are increasing availability of family day care, securing the quality of day care surveillance, managing taxes and other societal responsibilities, pension security for home care of children and savings in municipal finances. The risks or harms are the lack of substitutes in private family day care, the children in home care being left outside the early childhood education services of the city and increasing numbers of staff." (PTLTK:22.4.2010.)

The rate of service money was relatively high when compared with other childcare benefits, being 400 EUR per month per child in home care, and the initiative was eventually implemented in 2011. The first part of this initiative did not concern a large number of families, as families with four or more children under school age are rare in Finland - only five percent of families have four or more children below the age of 18, making families with four or more children below the school age particularly rare (Statistics Finland, 2015). Consequently, this benefit was available only for a small number of families and the number of families using service money solely to take care of their children at home were low, averaging 20 in 2011. However, beginning from 2012, the terms of service money were changed as it was largely replaced with the national service voucher system (SIVLTK:10.1.2012) and the service money for families with four or more children was abolished.

The relatively strong preference for home care of young children continues to be a heatedly debated topic in Finland as women's long childcare leaves are often seen as problematic for women's working careers and for gender equality at large (e.g. Salmi, 2006). Thus, the decision to implement a benefit that strongly encourages (maternal) home care of children goes against the national gender contract, which has historically been built on the ideal of wage-worker motherhood (Rantalaiho, 1994). Even though the service money for childcare for families with four or more children was available to only a small number of families, offering a rather generous benefit solely for the care of a family's own children goes against the normative ideals of women-friendliness of a Nordic welfare state and the Finnish gender contract of wage-worker motherhood. This kind of strong shift towards the traditional local gender contract that emphasises longer periods of maternal home care of children does not correspond with the existing national gender contract. In this framework, it was not surprising that the benefit was abolished only a year after it was implemented. It could be seen that the abolishing of service money for families with four or more children was due to the controversial nature that the cash-for-childcare schemes have in Finland - and that this was a case were the national debates and ideals shaped the local level decision-making.

Since the start of 2012, service money has only been available for private family day care providers for the care of their own children who are below school age, if they also have additional 'care children' in home care. The family day care provider also has to have formal qualifications for family day care and have a business identification (SIVLTK:27.4.2016). The rate of service money for childcare is fairly generous, and it enables a longer home care period than the national child home care allowance. Child home care allowance is 341.27 EUR per month for one child under three years of age; 102.17 EUR per month for each additional child under three years of age, and 65.65 EUR per month for each additional child 
over three years of age but under school age (Kela, 2016). In comparison, service money is 400 EUR per child per month, and paid until the child reaches school age. Thus, it offers a financially much more appealing option for the home care of children than the national child home care allowance.

\section{Private family day care and the emergence of a new local gender contract}

As noted in the previous section, in Jyväskylä, the local policy alignment has been that those providing private family day care receive a financial compensation - service money - for the home care of their own children who are below school age. Following these developments, the number of private family day care providers in the city has more than doubled since the start of the recession. The number of private family day care providers was 42 in 2009 (Saari et al., 2009, 24), while in 2016 the number stood at 110 (Klemmari, 2016). Simultaneously with the growing numbers of private family day care providers, the availability of municipal family day care places has been rapidly decreasing in Jyväskylä (SotkaNet, 2016c). Thus, the city seems to be aiming to move the emphasis of family day care from public to private service provisions.

In 2009, the women who had started as private family day care providers in the city were all mothers of young children who were taking care of their children at home, together with the additional child(ren) under care (Saari et al. 2009). Unfortunately, more recent numbers are not available, but it could be considered as highly likely that the majority of private family day care providers in the city are still mothers of young children. For women, becoming a private family day care provider can be a job market solution, an expansion to stay-at-home motherhood or a solution to adapting to the contradictory demands of family and working life (Tikka, 2007). In a city where the situation of highly educated mothers of young children in the local labour market is challenging (Sihto, 2015) and the overall unemployment level is relatively high (SotkaNet, 2015), starting as a private family day care provider can also be a way for women to cope with the difficult situation in the local labour market.

The growing role of private family day care and availability of service money for private family day care providers are two intertwining local developments that constitute a new hybrid form of childcare where entrepreneurship is combined with traditional homemaking. Together with cutbacks and marketisation developments, which indicate the diminishing role of the public sector and the growing role of individual choice and responsibility regarding childcare, these developments are creating a new local gender contract for women, which is here identified as the 'entrepreneurial homemaker' gender contract. This new local gender contract goes beyond the previous traditional or modern models of local gender contracts (Forsberg, 1998) by combining the 'entrepreneurial spirit', which is argued to become more and more valued in different spheres of life in contemporary society (Pyykkönen, 2014), with extensive periods of stay-at-home motherhood. 'Entrepreneurial' is here defined as both the ideal of individual choice and responsibility getting a stronger emphasis in childcare arrangements. Becoming a private family day care provider can be seen as an example of this: it allows one more option to families in organising child day care. However, this option is not without risks, as private family day care providers 
are also entrepreneurs, who are required to have business identification and compete about customers (the additional 'care children') with other private family day care providers.

These local level developments are tied together with the changes of the national gender contract from wage-worker motherhood (Rantalaiho, 1994) to the precarious worker/temporary homemaker gender contract, which relies less on the idea of work as a source of citizenship for women, and more on the neofamilistic tendencies that emphasise women's traditional caring role (Koskinen Sandberg, 2016). The local 'entrepreneurial homemaker' gender contract is also tied to neofamilistic tendencies, as it promotes longer periods of home care of children. Women are encouraged to take care of their children at home for extended periods of time, but the difference with the national level is that this is done in the framework of entrepreneurship, by becoming a private family day care provider. Thus, these women are not solely stay-at-home mothers, but are also included in the labour force, albeit with a relatively low salary and the risks that come with entrepreneurship.

\section{Conclusions}

The aim of this article was to examine the changes in local childcare policy in the city of Jyväskylä and to analyse how the local gender contract is being updated via these local level changes in childcare policy. The analysis shows how cutbacks in the city have been directed to both familistic and defamilistic childcare services and benefits. The number of children in municipally financed child day care has been falling at the local level. Simultaneously, also the number of children in home care has also been decreasing locally. Both of these developments in the city are likely due to the growing use of service vouchers in purchasing private child day care services.

Overall, marketisation has been a growing trend post-2008, as the city has been looking for more cost-effective solutions in the organisation of childcare. The marketisation development has partly gone hand-in-hand with gender traditionalism. Service money and the growing role of private family day care constitute a new hybrid form of childcare where entrepreneurship is combined with traditional homemaking. Together these developments are creating a new gender contract which goes beyond the previous traditional or modern models. This new local gender contract of 'entrepreneurial homemaker' is, to a certain extent, tied together with the national developments of women moving towards the gender contract of 'precarious worker/temporary homemaker' (Koskinen Sandberg 2016). However, what distinguishes the changes in the local gender contract from the national is the entrepreneurial emphasis at the local level. Home care of children is encouraged, but this is done in the framework of entrepreneurship, by becoming private family day care providers. As the case of service money for families with four or more children shows, paying money solely for the home care of one's children goes against the national gender contract of wage-worker motherhood (Rantalaiho, 1994), where periods of homemaking exist, but those periods are characterised by their temporary nature, centred around the time when the youngest child of the family is below the age of three (Statistics Finland, 2012). However, a different picture, more fitting with the existing national gender contract, emerges when home care of children is combined with being an entrepreneur. The overall development of marketisation of childcare also puts more emphasis on the ideals of individual choice and responsibility in deciding on 
the preferred form of childcare. These ideals go together with the rising of the entrepreneurial spirit in different spheres of life in contemporary society (Pyykkönen, 2014).

Local welfare policies are crucial in either supporting or discouraging female employment (Kutsar \& Kuronen, 2014), and thus shaping the local gender contract. Local child day care services play a central role in enabling or disabling female labour market participation. A study by Kuronen et al. (2014) showed how recent trends in the city of Jyväskylä have gone towards subsidising non-public forms of childcare, such as the use of private child day care services, with the aim of reducing the city's spending on childcare. Familistic tendencies have previously been more distinctive at the local level than in national policy-making (Kuronen et al., 2014) and the rhetoric of choice (Varjonen, 2011) has dominated the making of local childcare policy. In local policy documents changes were first and foremost justified with financial considerations (see Kari-Björkbacka, 2015) and the possible gendered implications of these changes remained hidden (see Autto, 2016). In local decision making, the goals for gender equality and facilitating female labour market participation were largely disregarded. Gender equality, which plays a major part in parliamentary debates, was absent in the context of local policy making (ibid.).

As noted in previous research (e.g. Karamessini \& Rubery, 2014), the goals for gender equality often get brushed aside during times of economic downturn and austerity, as policy rhetoric heightens the role of women as mothers and caregivers in families whilst simultaneously, policy-making focuses first and foremost on dealing with budget deficits and cutting public expenditure in the short term. This can eventually risk losing the progress towards gender equality that has been achieved in the past (ibid.) especially if the reforms and cutbacks that have been made during times of austerity are kept in force also in times of economic growth, as has happened previously in Finland. During the 1990s deep economic depression, the Finnish childcare policy system became less generous. However, even during periods of rapid economic growth, Finland has kept the cutbacks from the 1990s in force and allowed inflation to further erode existing benefits. (Hiilamo, 2006.) Thus, it could be considered likely that many of the cutbacks and changes that have been made in childcare policy post-2008 both locally and nationally will also be kept in force in the long run, despite changes in the economic cycle over time.

Studies in other countries (e.g. Penn, 2009; Lloyd \& Penn, 2010) have shown the problematic nature of marketisation of child day care. In a country like Finland, where child day care has relied on public provision and universal access to services for decades, the development towards marketisation means a strong shift in the existing paradigm. As the development towards marketisation of childcare is just getting started in Finland, there is very little research available regarding these issues. Studying particularly cities hailed for their innovativeness and role as forerunners can help to understand not only the changing societal structures families, particularly mothers, face in making choices regarding work and childcare, but also the direction towards which the national childcare policy model, and more broadly even the Nordic childcare policy model, could be developing in the future. As public child day care services have been one of the building blocks of Nordic 'women-friendliness' (Leira, 2002; Julkunen, 1994), more analysis is needed on what these changes in childcare policy mean for the normative basis and the 'women-friendliness' of the Nordic welfare state model at large. 


\section{References}

Alila, K., Eskelinen, M., Estola, E., Kahiluoto, T. and Kinos, J. (2014) Varhaiskasvatuksen historia, nykytila ja kehittämisen suuntalinjat: Tausta-aineisto varhaiskasvatusta koskevaa lainsäädäntöä valmistelevan työryhmän tueksi. Opetus ja kulttuuriministeriön työryhmämuistioita ja selvityksiä 2014:12. Helsinki, Opetus- ja kulttuuriministeriö.

Autto, J. (2016) When policymakers and parents meet political discourses: Fields and subject positions in the Finnish debates on children's day care. Social Politics: International Studies in Gender. State \& Societv, 23(1), 94-118.

Bowen, G.A. (2009) Document analysis as a qualitative research method. Qualitative research iournal. 9(2) 27-40.

Brennan, D., Cass, B., Himmelweit, S., \& Szebehely, M. (2012) The marketisation of care: Rationales and consequences in Nordic and liberal care regimes. Journal of European Social Policv, 22(4), 377-391.

Burau, V. and Kröger, T. (2004) The local and the national in community care: Exploring policy and politics in Finland and Britain. Social Policv \& Administration, 38(7), 793-810.

Caretta, M.A. and Börjeson, L. (2015) Local gender contract and adaptive capacity in smallholder irrigation farming: A case study from the Kenyan drylands. Gender. Place \& Culture, 22(5), 644-661.

Findikaattori. (2016) Male and female recipients of the child home care allowance. Available from: http://www.findikaattori.fi/en/111 [Accessed $3^{\text {rd }}$ October 2016].

Forsberg, G. (1998) Regional variations in the gender contract: Gendered relations in labour markets, local politics and everyday life in Swedish regions. Innovation: the European journal of social science research, 11(2), 191-209.

Forsberg, G. (2001) The difference that space makes. A way to describe the construction of local and regional gender contracts. Norsk geografisk tidsskrift. 55(3). 161-165.

Forsberg, G. (2010) Gender, geography and spatial practice. In: Hermelin, B., \& Jansson, U. (eds.) Placing human geography: Sweden through time and space. Stockholm, SSAG, pp. 209-222.

Grimsrud, G.M. (2011) Gendered spaces on trial: the influence of regional gender contracts on in-migration of women to rural Norway. Geografiska Annaler: Series B, Human Geography, 93(1), 3-20.

Haataja, A.(2012) Lastenhoidon tavoitteet ja toteutus: paikallinen ristiriidassa kansallisen kanssa? In: Mikkola, H., Blomgren, J., \& Hiilamo, H. (eds.) Kansallista vai paikallista? Puheenvuoroja sosiaali- ja terveydenhuollosta. Helsinki, Kelan tutkimusosasto, pp. 164-175. 
Heikkilä, M. and Törmä, S. (1996) Kokemuksia markkinaehtoisesta päivähoidostaväliraportti lasten päivähoidon valtakunnallisesta palvelurahakokeilusta. Helsinki, Sosiaalija Terveysministeriö.

Hernes, H. M. (1987) Welfare State and Woman Power: Essays in State Feminism. Oslo, Norwegian University Press.

Hiilamo, H. (2006) Woman-friendliness and economic depression: Finland and Sweden in the 1990s. In: Ellingsæter, A. L. \& Leira, A. (eds.) Politicising parenthood in Scandinavia. Gender relations in welfare states. Bristol, Policy Press, pp. 171-194.

Hirdman, Y. (1996) Key Concepts in Feminist Theory. Analysing Gender and Welfare. Aalborg, Department of History, International and Social Studies, Aalborg University. FREIA's tekstserie, 34 .

Ikonen, H.M. (2013) Epävarma työ, yrittäjätapaisuus ja paikkatunne: syrjäseudun naisen esimerkki. Työelämän tutkimus 11(1): 34-49.

Jallinoja, R. (2006) Perheen vastaisku: familistista käännettä jäljittämässä. Helsinki: Gaudeamus.

Jolkkonen, A. (1998) Paikan vaihto. Tutkimus irtisanomisuhan alaisten naisten työmarkkinastrategioista ja paikallisista työmarkkinoista. Joensuu, Joensuun yliopiston yhteiskuntatieteellisiä julkaisuja, 29.

Julkunen, R. (1994) Suomalainen sukupuolimalli - 1960-luku käänteenä. In: Anttonen, A., Henriksson, L. \& Nätkin, R. (eds.) Naisten hyvinvointivaltio. Tampere, Vastapaino, pp. 179201.

Karamessini, M. \& Rubery, J. (eds.) (2014) Women and Austerity. The Economic Crisis and the Future for Gender Equality. New York, Routledge.

Kari, I. (2009) Naistoimijuuden sulkeumia ja avauksia alueella ja työssä. Naistutkimus 22 (2009): 4.

Kari-Björkbacka, I. (2015) Alueen ja työn sukupuoli. Rovaniemi, Acta Universitas Lapponiensis, 306.

Karisto, A., Takala, P. \& Haapola, I. (1997) Matkalla nykyaikaan. Elintason, elämäntavan ja sosiaalipolitiikan muutos Suomessa. Helsinki, Sanoma Pro.

Kela. (2014) Benefits for families with children. Available from:

http://www.kela.fi/web/en/families;jsessionid=C71904C0D4B987EABFF37B8B4772241D [Accessed 24 ${ }^{\text {th }}$ August 2016].

Kela. (2016) Child home care allowance. Available from:

http://www.kela.fi/web/en/child-home-care-allowance [Accessed $4^{\text {th }}$ November 2016]. 
Klemmari. (2016) Available from:

https://www.klemmari.info/jyvaskyla/palveluhaku?s=1\&pTyyppi=1\&ylaluokka=11\&alaluok $\underline{\mathrm{ka}=75 \& \text { palvelu }=13 \& \text { asuinalue }}=\left[\right.$ Accessed $4^{\text {th }}$ November 2016].

Koskinen Sandberg, P. (2016) The Politics of Gender Pay Equity: Policy Mechanisms, Institutionalised Undervaluation, and Non-Decision Making. Helsinki: Hanken School of Economics, Department of Management and Organisation, Management and Organisation: Economics and Society, 305.

Kröger, T. (2011) Retuning the Nordic welfare municipality: Central regulation of social care under change in Finland. International Journal of Sociologv and Social Policv, 31(3/4), 148159.

Kuronen, M., Kröger, T., Antón-Alonso, F., Cucca, R., Escobedo, A., Jensen, P. H. \& Sabatinelli, S. (2015) The relationships between local and national childcare policies - A comparison of Nordic and Southern European Cities. In: Kutsar. D. \& Kuronen. M. (eds.) Local welfare policv making in European cities. London. Springer, pp. 119-134.

Kutsar, D. \& Kuronen, M. (eds.) (2015) Local Welfare Policy Making in Euronean Cities. London, Springer.

Lammi-Taskula, J. \& Salmi, M. (2013) Perhevapaat ja sukupuolten tasa-arvo. In: Pietiläinen, M. (ed.) Työ, talous ja tasa-arvo. Helsinki. Tilastokeskus, pp. 187-194.

Leavy, P. L. (2007) The feminist practice of content analysis. In: Hesse-Biber. S. N. \& Leavy, P. L. (Eds.) Feminist research practice. Thousand Oaks, CA, Sage, pp. 249-292.

Leira, A. (2002) Updating the" gender contract"? Childcare reforms in the Nordic countries in the 1990s. NORA: Nordic Journal of Women's Studies, 10(2), 81-89.

Lloyd, E. \& Penn, H. (2010) Why do childcare markets fail?: Comparing England and the Netherlands. Juncture, 17(1), 42-48.

Mahon, R., Anttonen, A., Bergqvist, C., Brennan, D. and Hobson, B. (2012) Convergent care regimes? Childcare arrangements in Australia, Canada, Finland and Sweden. Journal of European Social Policv, 22(4), 419-431.

Miettunen, L. (2008) Lasten kotihoidon tuen kuntalisät osana suomalaista päivähoitojärjestelmää. Helsinki, Kela.

Penn, H. (2009) International perspectives on quality in mixed economies of childcare. National Institute Economic Review, 207(1), 83-89.

Perrons, D. (1995) Gender inequalities in regional development. Regional Studies, 29(5), $465-476$.

Pyykkönen, M. (2014) Ylistetty Yrittäjyys. Jyväskylä, Jyväskylän yliopisto.

Rantalaiho, L. (1994) Sukupuolisopimus ja Suomen malli. In: Anttonen, A., Henriksson, L. \& Nätkin, R. (eds.) Naisten hyvinvointivaltio. Tampere. Vastapaino, pp. 9-30. 
Saari, E., Riikonen, H., Kivisaari, S., \& Heikkilä, A. (2009) Jyväskylän uudet päivähoitoratkaisut. Espoo: VTT Technical Research Centre of Finland.

Salmi, M. (2006) Parental choice and the passion for equality in Finland. In: Ellingsæter, A.L. and Arnlaug, L. (eds.) Politicising parenthood in Scandinavia: Gender relations in welfare states. Bristol. Policy Press, pp. 145-171.

Sihto, T. (2015) Choosing to work? Mothers return-to-work decisions, social class, and the local labor market. Nordic Journal of Working Life Studies, 5(3), 23.

SotkaNet. (2016a) Available from:

https://www.sotkanet.fi/sotkanet/en/taulukko/?indicator=s86ytDbRM7Qu1AcA\&region=szb MsbaIAgA $=\&$ year $=$ sy4rs87W0zUEAA $==\&$ gender $=\mathrm{t} \& a b s=\mathrm{f} \&$ color $=\mathrm{f}$ [Accessed 13 th September 2016].

SotkaNet. (2016b) Home care allowance, recipient families during year Available from: https://www.sotkanet.fi/sotkanet/en/taulukko/?indicator $=\mathrm{s} 64 \mathrm{qBgA}=\&$ region $=$ szbMAQA $=\&$ ye

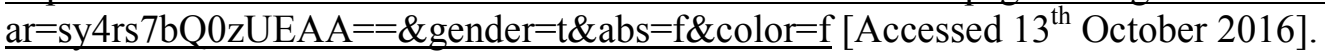

SotkaNet. (2016c) Family day care, children in services funded by the municipality Available from:

https://www.sotkanet.fi/sotkanet/en/taulukko/?indicator=sy6osjb0BQA=\&region=szbMAQA $=\&$ year $=$ sy 4 rs $07 \mathrm{~T} 0 \mathrm{zUEAA}==\&$ gender $=\mathrm{t} \& \mathrm{abs}=\mathrm{f} \&$ color $=\mathrm{f}\left[\right.$ Accessed $13^{\text {th }}$ October 2016].

SotkaNet. (2017) Unemployed people, as \% of labour force. Available from:

https://www.sotkanet.fi/sotkanet/en/taulukko/?indicator=szYKBAA=\&region=szbMsbaIAgA $=\&$ year $=$ sy4rty7U0zUEAA $==\&$ gender $=\mathrm{m} ; f ; t \& a b s=f \&$ color $=f$ [Accessed $8^{\text {th }}$ March 2017].

Statistics Finland. (2012) Families and work in 2011. Available from:

http://tilastokeskus.fi/til/tyti/2011/15/tyti 2011 15 2012-11-06 kat 003 en.html [Accessed $17^{\text {th }}$ December 2016].

Statistics Finland (2015) There are 1.5 million families. Available from:

http://tilastokeskus.fi/til/perh/2014/perh_2014_2015-05-28 tie_001_en.html [Accessed 2nd April 2017]

Statistics Finland (2016a) Employment and unemployment in 2015. Available from: http://www.stat.fi/til/tyti/2015/13/tyti $2015 \quad 13 \quad 2016-04-12$ kat 002 en.html [Accessed 2nd April 2017]

Statistics Finland. (2016b) Jyväskylä - kuntatiedot Available from:

http://tilastokeskus.fi/tup/kunnat/kuntatiedot/179.html [Accessed $17^{\text {th }}$ December 2016]

Suomen yrittäjät (2015) Palveluseteli - Tehoa ja joustoa. Selvitys 30 suurimman kunnan palvelusetelikokemuksista. Helsinki, Suomen yrittäjät.

Tikka, T. (2007) Taitavaksi hoitajaksi, arvostetuksi kasvattajaksi: ammatillinen sosialisaatio perhepäivähoitajan työssä. Joensuu, Joensuun yliopisto. 
Varjonen, S. (2011) Äidin hoiva, jaettu vanhemmuus - ja vapaus valita.

Perhevapaiden uudistamisen argumentointi 1970-luvulta 2000-luvulle. Sosiaali--ja terveysturvan tutkimuksia, 118. Helsinki, Kela.

Yin, R.K. (2009) Case Study Research. Design and Methods. Applied Social Research Methods Series Volume 5. Fourth edition. Thousand Oaks, CA, Sage. 
Table 1. Unemployed, as\% of labour force in Jyväskylä and in Finland

\begin{tabular}{|l|l|l|l|l|l|l|l|l|l|l|l|l|}
\hline & $\mathbf{1 9 9 1}$ & $\mathbf{1 9 9 5}$ & $\mathbf{2 0 0 0}$ & $\mathbf{2 0 0 5}$ & $\mathbf{2 0 0 8}$ & $\mathbf{2 0 0 9}$ & $\mathbf{2 0 1 0}$ & $\mathbf{2 0 1 1}$ & $\mathbf{2 0 1 2}$ & $\mathbf{2 0 1 3}$ & $\mathbf{2 0 1 4}$ & $\mathbf{2 0 1 5}$ \\
\hline JYV total & 6.6 & 23.2 & 16.5 & 13.9 & 11.0 & 12.9 & 13.0 & 12.4 & 13.2 & 15.0 & 16.7 & 17.6 \\
\hline FIN total & 8.6 & 19.3 & 12.8 & 10.8 & 8.0 & 10.3 & 10.1 & 9.4 & 9.8 & 11.3 & 12.4 & 13.4 \\
\hline JYV women & 7.5 & 21.7 & 17.2 & 14.0 & 11.0 & 11.5 & 11.3 & 11.0 & 11.5 & 13.0 & 14.6 & 15.6 \\
\hline FIN women & 9.9 & 18.2 & 13.2 & 10.6 & 7.7 & 8.6 & 8.6 & 8.2 & 8.5 & 9.8 & 10.8 & 11.8 \\
\hline
\end{tabular}

(Source: SotkaNet 2017) 
Table 2. Children in municipally funded full-time day care as \% of total population of same age

\begin{tabular}{|l|l|l|l|l|l|l|}
\hline & 1997 Jyv & 1997 Fin & 2007 Jyv & 2007 Fin & 2014 Jyv & 2014 Fin \\
\hline Aged 1-2 & 34.0 & 31.8 & 31.3 & 35.4 & 24.2 & 35.4 \\
\hline Aged 3-5 & 56.3 & 51.6 & 54.4 & 61.2 & 47.0 & 63.5 \\
\hline Aged 1-5 & 51.2 & 49.3 & 46.9 & 53.9 & 45.1 & 55.8 \\
\hline Aged 1-6 & 57.3 & 53.9 & 48.9 & 55.6 & 48.0 & 57.8 \\
\hline
\end{tabular}

(SotkaNet, 2016a) 
Records from Board of Education

\begin{tabular}{|l|}
\hline SIVLTK:9.11.2016 \\
\hline SIVLTK:12.10.2016 \\
\hline SIVLTK:21.9.2016 \\
\hline SIVLTK:24.8.2016 \\
\hline SIVLTK15.6.2016 \\
\hline SIVLTK:18.5.2016 \\
\hline SIVLTK:27.4.2016 \\
\hline SIVLTK:30.3.2016 \\
\hline SIVLTK:24.2.2016 \\
\hline SIVLTK:27.1.2016 \\
\hline SIVLTK:9.12.2015 \\
\hline SIVLTK:25.11.2015 \\
\hline SIVLTK:28.10.2015 \\
\hline SIVLTK:23.9.2015 \\
\hline SIVLTK:26.8.2015 \\
\hline SIVLTK:17.6.2015 \\
\hline SIVLTK:19.5.2015 \\
\hline SIVLTK:20.4.5.2015 \\
\hline SIVLTK:26.3.2015 \\
\hline SIVLTK:18.3.2015 \\
\hline SIVLTK:18.2.2015 \\
\hline SIVLTK:17.12.2014 \\
\hline SIVLTK:19.11.2014 \\
\hline SIVLTK:22.10.2014 \\
\hline SIVLTK:24.9.2014 \\
\hline SIVLTK:27.8.2014 \\
\hline SIVLTK:11.6.2014 \\
\hline SIVLTK:14.5.2014 \\
\hline SIVLTK:16.4.2014 \\
\hline SIVLTK:19.3.2014 \\
\hline SIVLTK:19.2.2014 \\
\hline SIVLTK:22.1.2014 \\
\hline SIVLTK:4.12.2013 \\
\hline SIVLTK:20.11.2013 \\
\hline SIVLTK:9.10.2013 \\
\hline SIVLTK:18.9.2013 \\
\hline SIVLTK:28.8.2013 \\
\hline SIVLTK:7.8.2013 \\
\hline SIVLTK:12.6.2013 \\
\hline SIVLTK:14.5.2013 \\
\hline SIVLTK:17.4.2013 \\
\hline SIVLTK:20.3.2013 \\
\hline SIVLTK:19.2013 \\
\hline SIVLTK:30.1.2013 \\
\hline SIVLTK:11.12.2012 \\
\hline
\end{tabular}

(c) Emerald Publishing Limited

This is a pre-print of a paper and is subject to change before publication. This pre-print is made available with the understanding that it will not be reproduced or stored in a retrieval system without the permission of Emerald Publishing Limited. 


\begin{tabular}{|l|}
\hline SIVLTK:30.10.2012 \\
\hline SIVLTK:18.9.2012 \\
\hline SIVLTK:28.8.2012 \\
\hline SIVLTK:5.6.2012 \\
\hline SIVLTK:24.4.2012 \\
\hline SIVLTK:27.3.2012 \\
\hline SIVLTK:7.2.2012 \\
\hline SIVLTK:10.1.2012 \\
\hline
\end{tabular}

Records from Board of Social Services and Health

\begin{tabular}{|l|}
\hline PTLTK:15.12.2011 \\
\hline PTLTK:24.11.2011 \\
\hline PTLTK:27.10.2011 \\
\hline PTLTK:6.10.2011 \\
\hline PTLTK:8.9.2011 \\
\hline PTLTK:25.8.2011 \\
\hline PTLTK:10.8.2011 \\
\hline PTLTK:16.6.2011 \\
\hline PTLTK:9.6.2011 \\
\hline PTLTK:18.5.2011 \\
\hline PTLTK:28.4.2011 \\
\hline PTLTK:17.3.2011 \\
\hline PTLTK:17.2.2011 \\
\hline PTLTK:3.2.2011 \\
\hline PTLTK:20.1.2011 \\
\hline PTLTK:16.12.2010 \\
\hline PTLTK:2.12.2010 \\
\hline PTLTK:18.11.2010 \\
\hline PTLTK:14.10.2010 \\
\hline PTLTK:16.9.2010 \\
\hline PTLTK:19.8.2010 \\
\hline PTLTK:10.6.2010 \\
\hline PTLTK:27.5.2010 \\
\hline PTLTK:19.5.2010 \\
\hline PTLTK:22.4.2010 \\
\hline PTLTK:25.3.2010 \\
\hline PTLTK:18.3.2010 \\
\hline PTLTK:24.2.2010 \\
\hline PTLTK:18.2.2010 \\
\hline PTLTK:21.1.2010 \\
\hline PTLTK:17.12.2009 \\
\hline PTLTK:19.11.2009 \\
\hline PTLTK:5.11.2009 \\
\hline PTLTK:29.10.2009 \\
\hline PTLTK:1.10.2009 \\
\hline
\end{tabular}




\begin{tabular}{|l|}
\hline PTLTK:3.9.2010 \\
\hline PTLTK:20.8.2010 \\
\hline PTLTK:11.6.2009 \\
\hline PTLTK:14.5.2009 \\
\hline PTLTK:23.4.2009 \\
\hline PTLTK:19.3.2009 \\
\hline PTLTK:19.2.2009 \\
\hline PTLTK:22.1.2009 \\
\hline PTLTK:18.12.2009 \\
\hline
\end{tabular}

